\title{
The Development and Transformation of the
}

\section{Bank Card Market as an Imperative for}

\section{Digitalization: the Case of Central and Eastern European Countries}

\author{
Olena Sobolieva-Tereshchenko (iD) https://orcid.org/0000-0002-1086-1192 \\ Ph.D., Associate Professor, Borys Grinchenko Kyiv University \\ Chair of Finance and Economics, Kyiv, Ukraine \\ e-mail: o.tereshchenko@kubg.edu.ua
}

\author{
Olesya Moyseyenko iD https://orcid.org/0000-0002-4698-6843 \\ Ph.D. student, Kyiv National University of Trade and Economics, Kyiv, Ukraine \\ e-mail: olesya.moyseyenko@gmail.com
}

\author{
Valeriia Zharnikova (iD) https://orcid.org/0000-0002-4335-5149 \\ Ph.D. Student, Kyiv National University of Trade and Economics, Kyiv, Ukraine \\ e-mail: v.zharnikova@gmail.com
}

\begin{abstract}
The purpose of this study is to determine the development trends of the major determinants of the bank card market in eight countries of Central and Eastern Europe in the period from 2010 to 2019. Continuing a study carried out in 2018, further comparative analysis of the "Bank Cards Market Index" proposed earlier and based on a system of interrelated indicators of bank payment cards, ATMs and POS-terminals, was carried out. We provide an overview of the rankings of Ukraine, Belarus, Moldova, Russia, Romania, Poland, Hungary, Slovakia using international ranking systems such as "The Legatum Prosperity Index," "Doing Business," "The Index of Economic Freedom," and the "Bank Cards Market Index." Further studies of three international ranking systems, as well as the "Bank Cards Market Index," again confirmed the similarity of the development models of the bank card market in Poland and Ukraine. To study the impact of the digitalization of economics and Covid-19 on the bank card market, a deeper analysis of two cases (Poland and Ukraine, as two similar bank card markets) was carried out using the "Digital Evolution Index." In the course of the research, it was
\end{abstract}


concluded that the "Bank Cards Market Index" can be successfully used for further research of the banking sector of different countries. Also, the growth trend of cashless payments in the bank card market and the possible transformation of the market under the influence of Covid-19, and the global digitalization of economics were noticed. Taking into account the above trend, further studies of the system of interrelated indicators of bank payment cards, ATMs, and POS terminals should be carried out using the "Digital Evolution Index" or other international indexes that characterize the level of digitalization of the economy in the researched countries.

Keywords: bank, Poland, Ukraine, bank cards, indicators, ranking of countries, index, digital economy, digitalization

JEL: G15, G21, O12

\section{Introduction}

The ranking of Central and Eastern European Countries (CEECs) to assess the development of the banking sector is one of the topics discussed in the academic literature. The bank cards market of former socialist states, including Ukraine, Russia, Belarus, and Moldova, and European Union members (Romania, Poland, Hungary, Slovakia) is diverse. This diversity can be considered an opportunity for cooperation between CEECs to implement the best practices in different banking sectors, which is reflected in the constantly increasing interest in this phenomenon from management scholars.

Klement et al. (2016, pp. 115-126) estimated the economic and business rank of Slovakia, including an analysis of the position of some European Union countries. They also gave specific recommendations for focusing on the position of Slovakia among its closest competitor regions (i.e., the neighboring V4 countries of Poland, Hungary, and the Czech Republic).

Following this line of investigation, Ramskyi et al. (2017, pp. 163-174) analyzed the relationship between banking system transformation and the effective development of the Ukrainian economy. They determined that Ukraine's integration into the European Union was a way to strengthen the business environment. Based on evidence from Russian firms on the German market and ways to solve them, Panibratov et al. (2018, pp. 106-122) described the problems of entry modes and the liability of the effects of foreignness. They expressed the idea that exporters and investors experience significant negative effects from the lack of proper institutional and business knowledge of the host financial market.

In the paper about the bank cards market, Sobolieva-Tereshchenko (2018, pp. 2544) provided a comparative analysis and investigated the determinants of the estimate for Ukraine and its neighboring countries in Central and Eastern Europe. Additionally, specific recommendations for improving the position of Ukraine in the bank cards market were given, using Poland's experience.

The results of practical research of the development of the bank card market and payment card industry can be found in the papers of Russian authors, including Fe- 
dorova, Dorozhkina, Cherkashnev (2016, pp. 58-63) and Khetagurov (2018, pp. 16-24), among others. Meanwhile, a detailed study of the methodological and technological development of the payment card industry can be found in the works of foreign scholars, with the most significant results presented by Van and Linh (2019, pp. 7-16) and Świecka, Terefenko, and Paprotny (2020, pp. 5-13)

This study offers insights into the best European practice and the challenges of the bank cards market between 2009 and 2019. It will guide the strategic and investigation reasoning by identifying the key trends and innovative solutions that allowed some participants of the European bank cards market to be included in the ranking of countries.

The study is structured as follows: first, we provide an overview of existing international methods such as "The Legatum Prosperity Index 2019," "BDO International Business Compass 2019," and "The Index of Economic Freedom 2019," emphasizing the context of markets in neighboring countries such as Belarus, Hungary, Moldova, Poland, Romania, Russia, Slovakia and Ukraine. After that, we present the results of an empirical analysis of the bank cards market. Then, we introduce the research settings, explain the rank method chosen, and make conclusions, followed by a definition of the Bank Cards Market index (BCM Index) and a further ranking of Ukraine and researched countries. Afterwards, we conduct a comparative analysis of two cases (Poland and Ukraine) as two similar bank cards markets. Using this index method, we make conclusion about deepening the cooperation between Ukraine and Poland in the framework of Euro-integration that could contribute to an increase in the development of the bank cards market developing of both countries.

\section{Data, variables and methods}

Small and medium enterprises enter the foreign market and face negative effects because of the lack of business knowledge about the operation of digital financial and credit instruments such as bank payment cards. Information on an accessible network of cash withdrawal points and non-cash payment points is very important for organizing work with buyers and suppliers.

Accordingly, it is necessary to study the bank cards market in neighboring countries to understand the potential for the development and digitalization of SME businesses. The purpose of the research is to make a comparative analysis of the bank cards market of Ukraine and neighboring countries to determine the connection between the influence of credit-financial instruments on stimulating business development, digitalization, and the digital transformation.

This study is based on two data sets from 2010 to 2019. The first shows information from the Legatum Prosperity Index, Doing Business, and Economic Freedom Index surveys in Central and Eastern Europe, such as Hungary, Poland, Romania, Slovakia, Belarus, Russia, Moldova and Ukraine.

The second data set is information from the website of the European Central Bank and websites of the central banks of those countries. We used three indicators to make 
our own calculations based on data from the banks of these countries. These indicators include information about bank cards, ATM and POS-terminals. Studying the two data sets together, we can obtain a data set to understand the possibility of the bank cards business development in each analyzed country.

The Legatum Prosperity Index ${ }^{\mathrm{Tm}}$ provides the performance of 167 nations across 65 policy-focused elements, measured by almost 300 country-level indicators. The "Legatum Prosperity Index survey makes the indexes a unique global benchmarking tool for determining a country's economic potential.

The Economic Quality pillar measures how well a state's economy is equipped to generate wealth sustainably and with the full engagement of its workforce. The comparative analysis of the Rank of Economic Quality in CEECs over the ten years is presented in Table 1.

Table 1. Legatum Prosperity Index for CEECs, 2010-2019

\begin{tabular}{|l|c|c|c|c|c|c|c|c|c|c|}
\hline \multirow{2}{*}{ Country } & \multicolumn{10}{|c|}{ LP Country Economic Quality } \\
\cline { 2 - 14 } & 2010 & 2011 & 2012 & 2013 & 2014 & 2015 & 2016 & 2017 & 2018 & 2019 \\
\hline Belarus & 42 & 54 & 47 & 40 & 41 & 47 & 48 & 42 & 40 & 54 \\
\hline Hungary & 57 & 56 & 59 & 60 & 59 & 54 & 53 & 57 & 44 & 31 \\
\hline Moldova & 96 & 91 & 91 & 86 & 79 & 84 & 84 & 90 & 90 & 101 \\
\hline Poland & 36 & 36 & 39 & 41 & 37 & 37 & 37 & 34 & 38 & 39 \\
\hline Romania & 63 & 64 & 68 & 84 & 75 & 71 & 71 & 60 & 60 & 40 \\
\hline Russia & 77 & 73 & 70 & 72 & 60 & 66 & 66 & 70 & 63 & 43 \\
\hline Slovakia & 38 & 44 & 48 & 49 & 50 & 50 & 50 & 49 & 37 & 27 \\
\hline Ukraine & 76 & 76 & 87 & 77 & 77 & 88 & 88 & 84 & 97 & 91 \\
\hline
\end{tabular}

Source: Legatum Prosperity Index (2020).

According to the data in the table, between 2010 and 2019, Moldova and Ukraine had the lowest Economic Quality ranking. The highest ranked country was Slovakia.

At the same time, for the majority of countries, 2015-2016 was the most stable period, according to the parameters of Legatum Prosperity Index, while the most non-stable period was the last two years. Between 2018 and 2019, the most volatile countries were Romania (-20) and Russia (-20). The most stable country was Poland $(+1)$.

The most well-known and popular methodology for assessing the establishment and support of business is "Doing Business," conducted by an international network of public accounting, tax, consulting and business advisory firms which perform professional services among 190 countries across all continents.

"Doing Business" is an annual report that studies the regulations that improve doing business and those that constrain it. It presents quantitative indicators on business regulation and the protection of property rights, which can be compared across 190 economies. It measures aspects of regulation that affect 11 areas of the life of a business, and the indicators are used to analyze economic outcomes and identify the results of business reforms. 
The Development and Transformation of the Bank Card Market as an Imperative for Digitalization...

Thus, the best conditions for business development in 2019 according to the "Doing Business" Index Rank were in Russia ( $31^{\text {st }}$ place), Poland ( $\left.33^{\text {rd }}\right)$ and Belarus $\left(37^{\text {th }}\right)$, which can be a benchmark for Ukraine (71 Rank) on determination of the potential of business development. Table 2 shows the attractiveness of Ukraine and other CEECs in 2010-2019 according to the "Doing Business" Rank.

Table 2. "Doing Business" Index for CEECs, 2010-2019

\begin{tabular}{|l|c|c|c|c|c|c|c|c|c|c|}
\hline \multirow{2}{*}{ Country } & \multicolumn{10}{|c|}{ Doing Business } \\
\cline { 2 - 14 } & 2010 & 2011 & 2012 & 2013 & 2014 & 2015 & 2016 & 2017 & 2018 & 2019 \\
\hline Belarus & 58 & 91 & 69 & 58 & 63 & 57 & 44 & 37 & 38 & 37 \\
\hline Hungary & 47 & 46 & 51 & 54 & 54 & 54 & 42 & 41 & 48 & 53 \\
\hline Moldova & 94 & 99 & 81 & 83 & 78 & 63 & 52 & 44 & 44 & 47 \\
\hline Poland & 72 & 59 & 62 & 55 & 45 & 32 & 25 & 24 & 27 & 33 \\
\hline Romania & 55 & 65 & 72 & 72 & 73 & 48 & 37 & 36 & 45 & 52 \\
\hline Russia & 120 & 124 & 120 & 112 & 92 & 62 & 51 & 40 & 35 & 31 \\
\hline Slovakia & 53 & 43 & 48 & 46 & 49 & 37 & 29 & 33 & 39 & 42 \\
\hline Ukraine & 142 & 149 & 152 & 137 & 112 & 96 & 83 & 80 & 76 & 71 \\
\hline
\end{tabular}

Source: World Bank Group (2018; 2019).

As the table shows, in this period, the analyzed countries increased their rankings, with the exception of Hungary (+6), which had the most negative dynamic. The most volatile countries were Russia (-89) and Ukraine (-71). Ukraine has a very good positive dynamic; over ten years, the country improved its "Doing Business" rank from $142^{\text {nd }}$ in 2010 to $71^{\text {st }}$ in 2019.

The "Index of Economic Freedom" methodology for assessing and supporting business conducted among 180 countries in the World is also popular. It uses 12 indicators to calculate the world rank for every country the index. The 12 indicators that make up the economic freedom score are equally weighted in determining the rankings. Table 3 presents the Index of Economic Freedom results for the period 2010-2019.

Table 3. Index of Economic Freedom for CEECs, 2010-2019

\begin{tabular}{|l|c|c|c|c|c|c|c|c|c|c|}
\hline \multirow{2}{*}{ Country } & \multicolumn{10}{c|}{ EF Economic Freedom } \\
\cline { 2 - 13 }$y$ & 2010 & 2011 & 2012 & 2013 & 2014 & 2015 & 2016 & 2017 & 2018 & 2019 \\
\hline Belarus & 48.7 & 47.9 & 49.0 & 48.0 & 50.1 & 49.8 & 48.8 & 58.6 & 58.1 & 57.9 \\
\hline Hungary & 66.1 & 66.6 & 67.1 & 67.3 & 67.0 & 66.8 & 66.0 & 65.8 & 66.7 & 65.0 \\
\hline Moldova & 53.7 & 55.7 & 54.4 & 55.5 & 57.3 & 57.5 & 57.4 & 58.0 & 58.4 & 59.1 \\
\hline Poland & 63.2 & 64.1 & 64.2 & 66.0 & 67.0 & 68.6 & 69.3 & 68.3 & 68.5 & 67.8 \\
\hline Romania & 64.2 & 64.7 & 64.4 & 65.1 & 65.5 & 66.6 & 65.6 & 69.7 & 69.4 & 68.6 \\
\hline Russia & 50.3 & 50.5 & 50.5 & 51.1 & 51.9 & 52.1 & 50.6 & 57.1 & 58.2 & 58.9 \\
\hline Slovakia & 69.7 & 69.5 & 67.0 & 68.7 & 66.4 & 67.2 & 66.6 & 65.7 & 65.3 & 65.0 \\
\hline Ukraine & 46.4 & 45.8 & 46.1 & 46.3 & 49.3 & 46.9 & 46.8 & 48.1 & 51.9 & 52.3 \\
\hline
\end{tabular}

Source: Miller, Kim, and Roberts (2019). 
According to Table 3, Ukraine had the worst Economic Freedom Rank among the analyzed countries every year during the ten years. This indicator varied from 46.4 in 2010 to 52.3 in 2019. At the same time, the Economic Freedom Rank was highest in Romania (64.2 in 2010 and 68.6 in 2019) and Poland (63.2 in 2010 and 67.8 in 2019).

So, a comparative analysis of the economic and business conditions in CEECs to determine the potential for business development shows that such ratings as "The Legatum Prosperity Index," "Doing Business," and "The Index of Economic Freedom" don't allow us to fully define the potential economic development of the bank cards market.

\section{Empirical results and discussions}

Every bank cards market in Central and Eastern Europe has different conditions. First of all, countries need to adapt to the modern business environment for their economic development and investment attractiveness. It is very important for them to understand their place among other competing countries, which can be done based on ranking data. Secondly, foreign companies that do business in other countries have a number of advantages. They can use information about the cards' business environment and high-quality supporting infrastructure combined with a convenient geographic location, which can also be done based on ranking data. Third, the level of distribution of non-cash payments using payment cards is one of the indicators of the development of the global system of cashless payments and the banking system in general.

Thus, two main criteria were identified to assess the key indicators of the bank card market: the existence of cards and the availability of support devices for cash withdrawals and card payments. The first is focused mainly on the issue of bank cards, and the second on the expansion of the number of POS-terminals and ATM networks.

The study was conducted in CEECs: Romania, Moldova, Hungary, Slovakia, Poland, Belarus, and Russia. The countries were ranked in alphabetical order for the analysis. A comparative analysis of the key indicators of the bank cards market among the analyzed countries over the ten years is presented in Table 4.

A comparison of the population of Ukraine and the analyzed countries showed that Poland is the closest indicator for Ukraine. All countries, except for Russia, have significantly smaller populations compared to Ukraine. Over the ten years, the population increased in Russia but decreased in Hungary, Romania, and Ukraine. The population of the other analyzed countries was relatively stable throughout the period.

Ukraine ranks third after Russia and Poland by the number of bank cards. The number of bank cards in Russia $(285.8 \mathrm{ml}$. pcs) significantly exceeds the indicators of all analyzed countries. The number of bank cards in Ukraine (42.2 $\mathrm{ml}$. pcs) is slightly less than in Poland (42.9 ml. pcs) 
The Development and Transformation of the Bank Card Market as an Imperative for Digitalization...

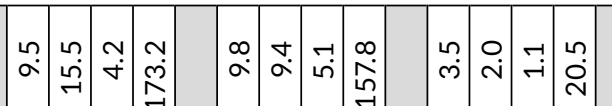

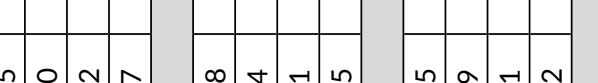

๙

å

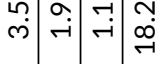

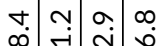

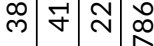

诗

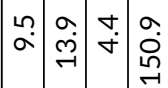

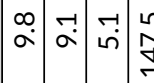

m)

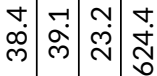

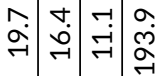

นุ

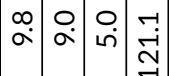

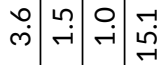

ळ.

ก. 0.70

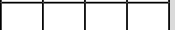

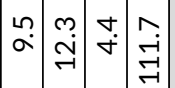

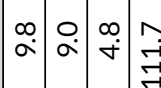

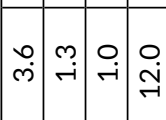

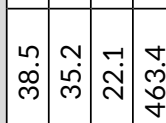

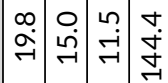

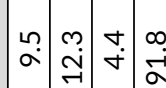

a $a .0$

\begin{tabular}{ll|l|l|}
\hline 0 & $m$ & -7 & n \\
\hline
\end{tabular}

mं

nก $-\pi$ in $N$

m లి

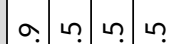



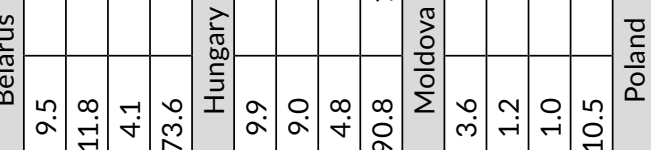

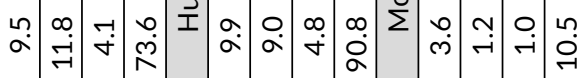

$\ln \wedge a$

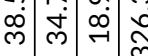

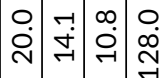

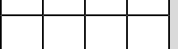

బุ.

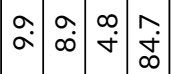

लें

ஓे

ư

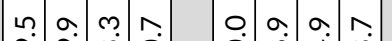

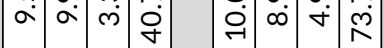

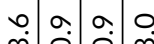

¿

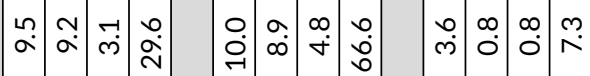

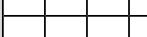

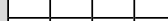

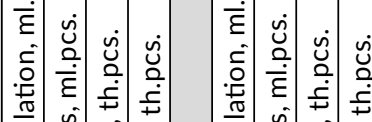

䆑

高至

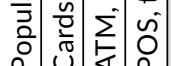

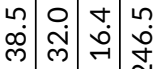

ㄴ.

in 0 l

ळ্ল

N N

ग न

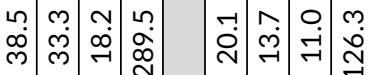




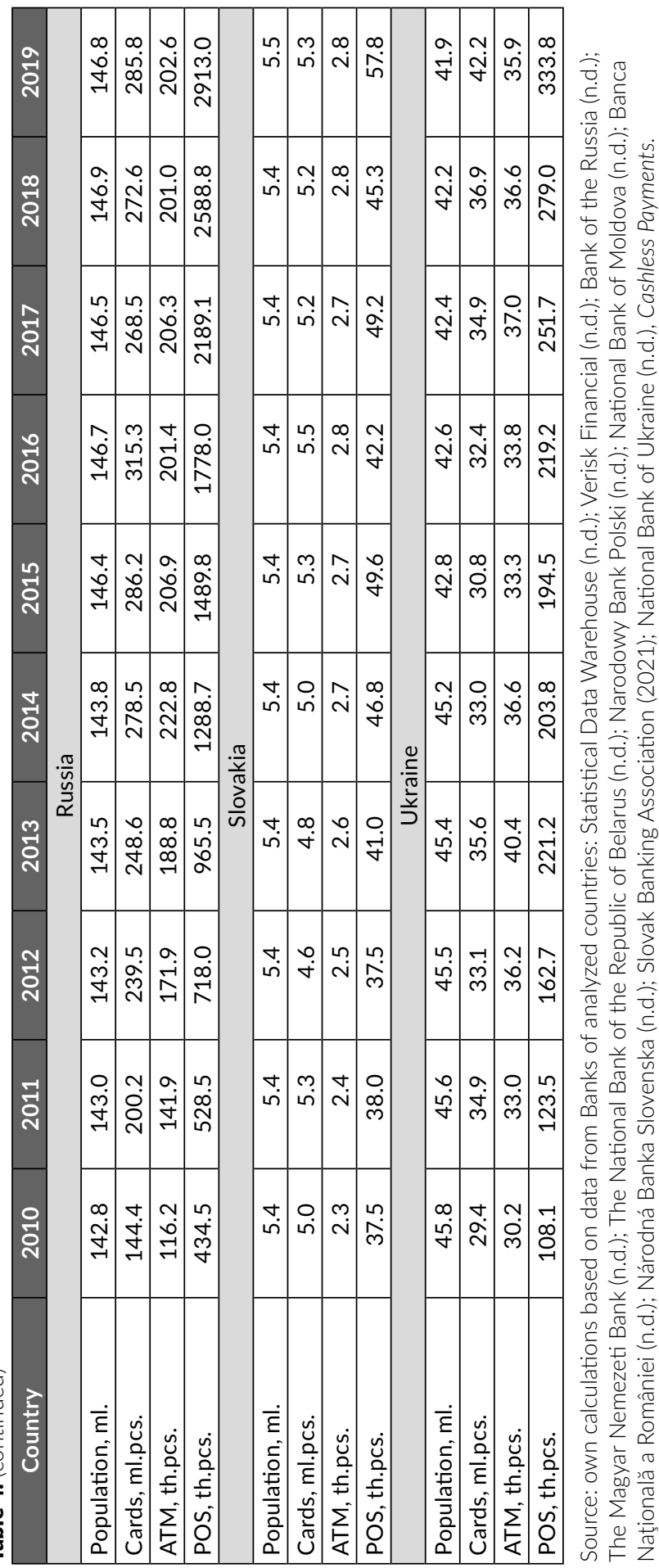


According to 2019 data, the number of bank cards is greater than the population in these three countries. The number of bank cards in Ukraine and Poland exceeds the population insignificantly. In Russia, there are two times more bank cards than people. Obviously, every adult in this country has two or three cards. On the one hand, these cards have different specific functions, and on the other, the second and third cards are used rarely.

Comparing the number of ATM network and POS-terminals showed that the Moldova has the fewest while Russia has the most. Ukraine ranks second after Russia by number of ATMs and third after Russia and Poland by number of POS-terminals.

The number of POS-terminals and ATMs increased in all analyzed countries between 2010 and 2019, but terminal growth rates were much higher than the ATM growth rate. During the last ten years, the number of POS-terminals in Belarus and Russia has increased almost six-fold, and in Ukraine and Poland, it has more than tripled. Meanwhile, the number of ATMs increased by $26 \%$ in Belarus, $43 \%$ in Russia, $16 \%$ in Ukraine, and $28 \%$ in Poland.

So, it seems that Ukraine has a developed ATM network and large number of POS-terminals among CEECs. The situation with key indicators of the bank cards market in Ukraine is similar to Poland. However, these absolute figures do not reflect the real conditions of the bank cards market. For the comparative analysis of the real conditions on the bank cards market, the estimation of the relative indicators is necessary. The best indicators are capacity and efficiency indicators.

\section{Methodology}

The European Central Bank (ECB) publishes the payments statistics in EU countries annually. This data set comprises a number of card and payment card accepting devices. However, this statistic does not contain a common indicator of the bank cards market or a ranking of EU countries. Additionally, this data set does not include information about non-EU countries.

Thereby, to understand the potential development of the bank cards market in CEECs, our investigation of the country ranking will be continued (Sobolieva-Tereshchenko 2018, pp. 25-44). The ECB data set and information from the sites of the National Bank of Ukraine and the central banks of countries were collected for comparative economic research.

Every country in Central and Eastern Europe has its own population, total number of bank cards, and payment card accepting devices. There indicators do not show the real conditions of the bank cards market, the best of which are the relative indicators.

The best criterion of card availability is the number of payment cards per capita, which is defined as the indices of the number of payment cards to the population of every country. The optimal criteria of ATM network are the number of cards per ATM, which is defined as the indices of the number of cards to the number of ATMs 
in the country. The best criteria of the number of POS-terminals is the number of cards per POS-terminal, which is defined as the indices of the number of cards to the number of POS-terminals in each country. The comparative analysis of the bank cards market in countries is presented in Table 5 .

The comparative analysis of the number of bank cards per capita in 2019 shows that this indicator in Ukraine is lower than in Russia, Belarus, and Poland, but higher than in other countries.

Between 2010 and 2019, the number of cards per capita gradually increased. In general, the increase in the number of bank cards was due to two reasons. Firstly, the number of POS-terminals where you can pay by card increased. Secondly, contactless and tokenized cards were actively issued as additional cards to the classic bank (plastic) cards.

A comparison of the ATM networks showed that Belarus had the largest number of cards per ATM while Ukraine had the fewest. CEECs and Ukraine had approximately the same number of cards, although the number of cardholders using ATMs in CEECs was more than in Ukraine. This indicates the excessive number of ATMs in Ukraine in comparison with CEECs.

Most countries increased the number of cards per ATM during last ten years. Only in Hungary, Slovakia, and Poland did the number of cards per ATM decrease in that period. Thus, Ukraine has the potential to reduce the ATM network, taking into account the average number of people per ATM in CEECs (1850 cards per ATM in 2019). The increased number of cards per ATM will contribute to a decrease in cash turnover and an intensification of the fight against the shadow economy.

In order to extend cashless settlements, countries increase the total number of terminals, reducing the number of cards per terminal. Among CEECs in 2019, Ukraine had the largest number of cards per POS-terminal, (130 cards per POS).

In the period from 2010 to 2019, in all analyzed countries, there was a decrease in the number of bank cards per POS terminal. The number of cards per POS terminal in Ukraine has decreased more than halved over the past ten years - from 270 pcs in 2010 to 130 pcs in 2019.

In 2019, in some European countries (for example, Hungary (0.06), Poland (0.05)) this indicator was much lower, but in others (for example, Belarus (0.09), Moldova (0.10), Slovakia (0.09) and Russia (0.10)) it reflected the average level in CEECs bank card market.

CEECs are helping to develop payment infrastructure as part of Europe's broader efforts to promote cashless payments. Increasing the number of cashless payments makes payments more transparent and fosters economic growth in EU countries. Therefore, Ukraine has the opportunity to increase the number of POS-terminals to extend cashless settlements and withdraw its economy from the shadow. Focusing on the CEECs, it should be noted that the best indicators of using the POS-terminals for payment card transactions is in Hungary and Poland. 
The Development and Transformation of the Bank Card Market as an Imperative for Digitalization...

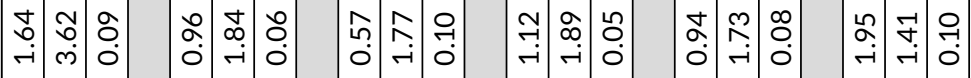

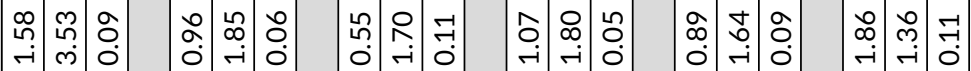

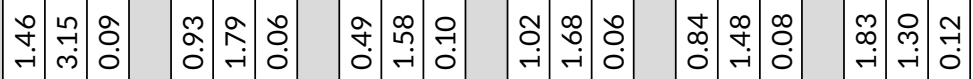

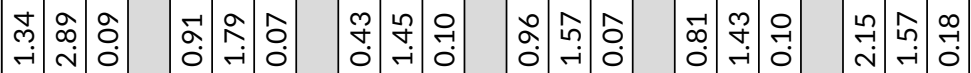

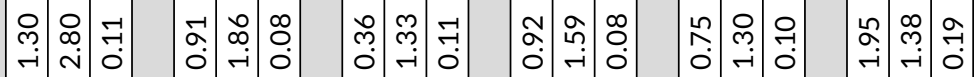

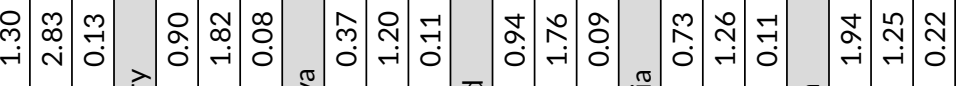

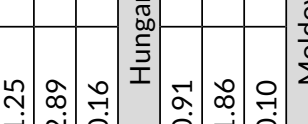

-

(a)

20

\section{둥}

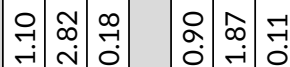

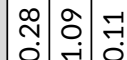

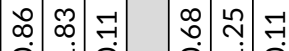

స̂े

\begin{tabular}{l|l} 
\\
\hline
\end{tabular}

স্்

$+$

\begin{tabular}{ll|l} 
& \\
\hline
\end{tabular}

(

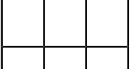

-

\section{\begin{tabular}{|l|l}
\hline \\
\hline
\end{tabular}}

० -0

०

- -10 


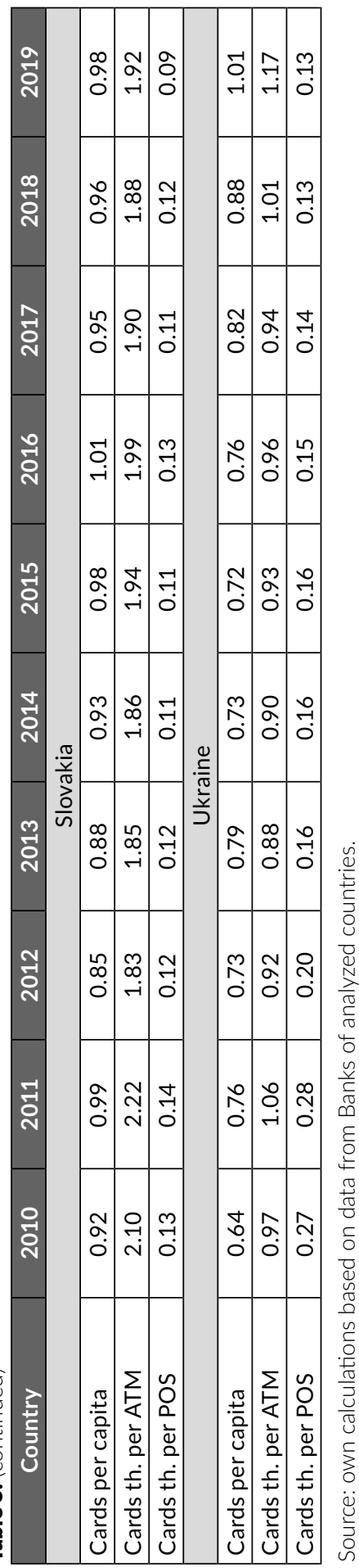


Thus, it is recommended to use three criteria for a comparative analysis of the bank cards market to determine the potential for the innovative development of economy in CEECs, i.e., card availability, size of the ATM network, and the number of POS-terminals.

To determine the level of development and transformation of the bank card market as an imperative for digitalization, we propose calculating the Bank Cards Market index (BCM index) in addition to "The Legatum Prosperity Index," "BDO International Business Compass," and "The Index of Economic Freedom".

In the BCM Index, the three components are weighted equally so that the overall score is not biased toward any one component or direction. The purpose of the index is to reflect the bank cards market in every country in a balanced way. The data for each component are provided so that others can study, weight, and integrate them for future investigations.

\section{Data analysis}

The comparative analysis of the BCM Index and the obtained ranking of CEECs will greatly foster the cooperation between EC countries, and the development and stability of the banking system. This cooperation will result in accessible online services of European standards that open new possibilities for countries in Central and Eastern Europe and their cardholders.

The goal of the BCM Index is simple: by illustrating how countries have moved toward or away from the number of cards, ATMs, and POS-terminals, we want to help to identify the best pathways of the bank cards market. To achieve this goal, the BCM Index describes the conditions required for development. We describe these conditions as the combination of three variables: the Number of cards per capita, the Number of cards per ATM, and the Number of cards per POS-terminal. Using data for the eight countries over twelve years, we track the journeys made by countries toward or away from the development of the bank cards market.

Each of the three variables has the same significant effect on the state of the payment market. It should be noted that when comparing countries and determining the rating, it is necessary to take into account certain features of each variable of the bank cards market. The highest number of cards per capita and the largest number of cards per ATM is a positive factor, and corresponds to the highest rating. Meanwhile, the highest number of cards per POS-terminal indicates a lack of equipment, and is a negative factor and corresponds to the lowest rating.

Each variable was assigned equal weight because each ranking covers a limited set of variables, which have equal importance. The mean of the three variables yields a country's overall BCM Index score. This scheme allows us to express our views of what is significant to the development of the economy, while also keeping it within the range of evidence available in countries' central banks and from expert opinions. 
The total IBCM Index was calculated as the average of the three indicators to determine the state of the Ukrainian bank cards market and compare it with market in CEECs. A comparative analysis of BCM Index based on the variables mentioned above is presented in Table 6.

Table 6. Comparative analysis of the BCM Index for CEECs, 2010-2019

\begin{tabular}{|l|c|c|c|c|c|c|c|c|c|c|}
\hline \multicolumn{1}{|c|}{ Country } & 2010 & 2011 & 2012 & 2013 & 2014 & 2015 & 2016 & 2017 & 2018 & 2019 \\
\hline Belarus & 3.3 & 3.0 & 3.0 & 3.0 & 3.0 & 2.7 & 2.0 & 2.3 & 2.3 & 2.7 \\
\hline Hungary & 4.0 & 4.0 & 2.0 & 2.3 & 3.0 & 3.3 & 3.3 & 3.0 & 3.3 & 4.0 \\
\hline Moldova & 5.3 & 5.7 & 5.7 & 6.3 & 6.3 & 6.7 & 6.3 & 6.3 & 6.0 & 6.3 \\
\hline Poland & 3.7 & 3.7 & 4.3 & 3.7 & 3.3 & 3.0 & 3.3 & 3.3 & 2.7 & 2.3 \\
\hline Romania & 4.7 & 4.7 & 5.3 & 5.0 & 5.0 & 5.3 & 5.7 & 5.0 & 5.0 & 5.3 \\
\hline Russia & 5.0 & 4.7 & 4.7 & 4.7 & 5.0 & 4.7 & 4.3 & 5.0 & 4.7 & 5.0 \\
\hline Slovakia & 3.3 & 3.3 & 4.0 & 4.0 & 3.3 & 3.0 & 3.7 & 3.3 & 4.3 & 3.7 \\
\hline Ukraine & 6.7 & 7.0 & 7.0 & 7.0 & 7.0 & 7.3 & 7.3 & 7.7 & 7.7 & 6.7 \\
\hline
\end{tabular}

Source: own calculations based on data from the central banks of the analyzed countries.

According to the data in the table, taking into account the three proposed criteria, Ukraine was ranked last in the rating during the whole period. Poland came first in 2019, improving its rating from 3.7 to 2.3 between 2010 and 2019. Thus, Ukraine has the potential for development and improvement in comparison with Poland.

We have chosen to focus on the BCM Index in light of the evidence that its development has a positive effect on wellbeing and economic growth in CEECs. This is supported by “The Legatum Prosperity Index," "Doing Business," “The Index of Economic Freedom".

Combining the two data sets together, we created a unique panel dataset from the "The Legatum Prosperity Index," "Doing Business," and "The Index of Economic Freedom" surveys and data from the websites of the central banks of the countries. The data set in 2010, 2014, and 2019 is presented in Table 7.

Table 7. Comparative analysis for the main rank variables for CEECs, 2010-2019

\begin{tabular}{|l|c|c|c|c|c|c|r|r|r|r|r|r|}
\hline \multirow{3}{*}{ Country } & \multicolumn{3}{|c|}{$\begin{array}{c}\text { BCM Index } \\
\text { proposed by the } \\
\text { author }\end{array}$} & \multicolumn{3}{c|}{$\begin{array}{c}\text { LP Country } \\
\text { Economic Rank }\end{array}$} & \multicolumn{3}{c|}{ Doing Business } & \multicolumn{3}{c|}{$\begin{array}{c}\text { EF Economic } \\
\text { Freedom }\end{array}$} \\
\cline { 2 - 18 } & 2010 & 2014 & 2019 & 2010 & 2014 & 2019 & 2010 & 2014 & 2019 & 2010 & 2014 & 2019 \\
\hline Belarus & 3.3 & 3.0 & 2.7 & 42 & 41 & 54 & 58 & 63 & 37 & 48.7 & 50.1 & 57.9 \\
\hline Hungary & 4.0 & 3.0 & 4.0 & 57 & 59 & 31 & 47 & 54 & 53 & 66.1 & 67.0 & 65.0 \\
\hline Moldova & 5.3 & 6.3 & 6.3 & 96 & 79 & 101 & 94 & 78 & 47 & 53.7 & 57.3 & 59.1 \\
\hline Poland & 3.7 & 3.3 & 2.3 & 36 & 37 & 39 & 72 & 45 & 33 & 63.2 & 67.0 & 67.8 \\
\hline Romania & 4.7 & 5.0 & 5.3 & 63 & 75 & 40 & 55 & 73 & 52 & 64.2 & 65.5 & 68.6 \\
\hline Russia & 5.0 & 5.0 & 5.0 & 77 & 60 & 43 & 120 & 92 & 31 & 50.3 & 51.9 & 58.9 \\
\hline Slovakia & 3.3 & 3.3 & 3.7 & 38 & 50 & 27 & 53 & 49 & 42 & 69.7 & 66.4 & 65.0 \\
\hline Ukraine & 6.7 & 7.0 & 6.7 & 76 & 77 & 91 & 142 & 112 & 71 & 46.4 & 49.3 & 52.3 \\
\hline
\end{tabular}

Source: own calculations based on data from Tables 1, 2, 3, and 6. 
As the table shows, Belarus, Poland and Slovakia have a BCM Index better than other countries between 2010 and 2019. At the same time, according to Economic Rank of "The Legatum Prosperity Index," Belarus, Poland and Slovakia take leading positions. According to the "Doing Business" rank, Hungary, Poland and Slovakia have the best positions. According to the rank of Financial Freedom from "The Index of Economic Freedom," Belarus, Russia, and Ukraine have good conditions for investment.

So, during the last ten years, Poland and Slovakia had the best positions according to the estimate of "The Legatum Prosperity Index," "Doing Business" and the BCM Index proposed by the author. The comparative analysis for "The Legatum Prosperity Index," "Doing Business," "The Index of Economic Freedom," and the "BCM Index" for Poland, Slovakia and Ukraine in 2010, 2014 and 2019 are represented in Figure 1.

The model is a visual representation of how the four indexes are interrelated in Slovakia, Poland and Ukraine. The model of Ukraine and Poland is similar. Thus, we conclude that deep cooperation between Ukraine and Poland in the framework of Euro-integration could help develop the bank cards market of both countries.

In 2020, the challenge of the Covid-19 pandemic and trend of digitalization put pressure on these indicators in many EC countries. European economies are among the most digitally inclusive (measuring gender, class, and geographic inclusion), and six European countries (Norway, Belgium, Switzerland, Austria, Iceland, and Poland) are included in the Digital Intelligence Index top 10. In CEECs, mobile internet access is expanding and has improved rapidly. Over $90 \%$ of the population in Poland are covered by $4 \mathrm{G}$ mobile networks now, while in Ukraine, $4 \mathrm{G}$ access has jumped from $2 \%$ to $75 \%$ since 2017 .

To understand the level of Digitalization in Poland, Slovakia and Ukraine, we additionally studied the Digital Evolution Index (DEI). The DEI created by the Fletcher School at Tufts University (with the support of Mastercard and Data Cash) and combines more than 358 indicators in two scorecards, the Digital Evolution State and Digital Evolution Momentum. Digital Evolution captures the state and rate (momentum) of digital evolution and identifies implications for investment, innovation, and policy priorities. The Digital Evolution Scores of Poland, Slovakia, Ukraine in 2020 are represented in Figure 2.

The graph shows that Poland and Slovakia have a higher state index than Ukraine, while Ukraine has a faster-moving economy in terms of the pace of change in its digital evolution (digital momentum) than Slovakia. Thus, we conclude that the deepening cooperation between Ukraine and Poland in the framework of using the experience of digitalization of the economy can contribute to greater development of the bank cards market in both countries.

According to the National Bank of Poland's report about the payment card market in Poland in Q1 2020, the share of contactless transactions in the value of all card payments was record-breaking. At the end of March 2020, it reached 84.1 percent. The previous record, recorded in the last quarter of 2019, was 81.4 percent. In the first 
quarter of 2020, there were 41.2 million different contact payment instruments on the market (plastic cards, virtual cards, stickers, etc.). More than 9 out of 10 card payments in Poland are contactless.

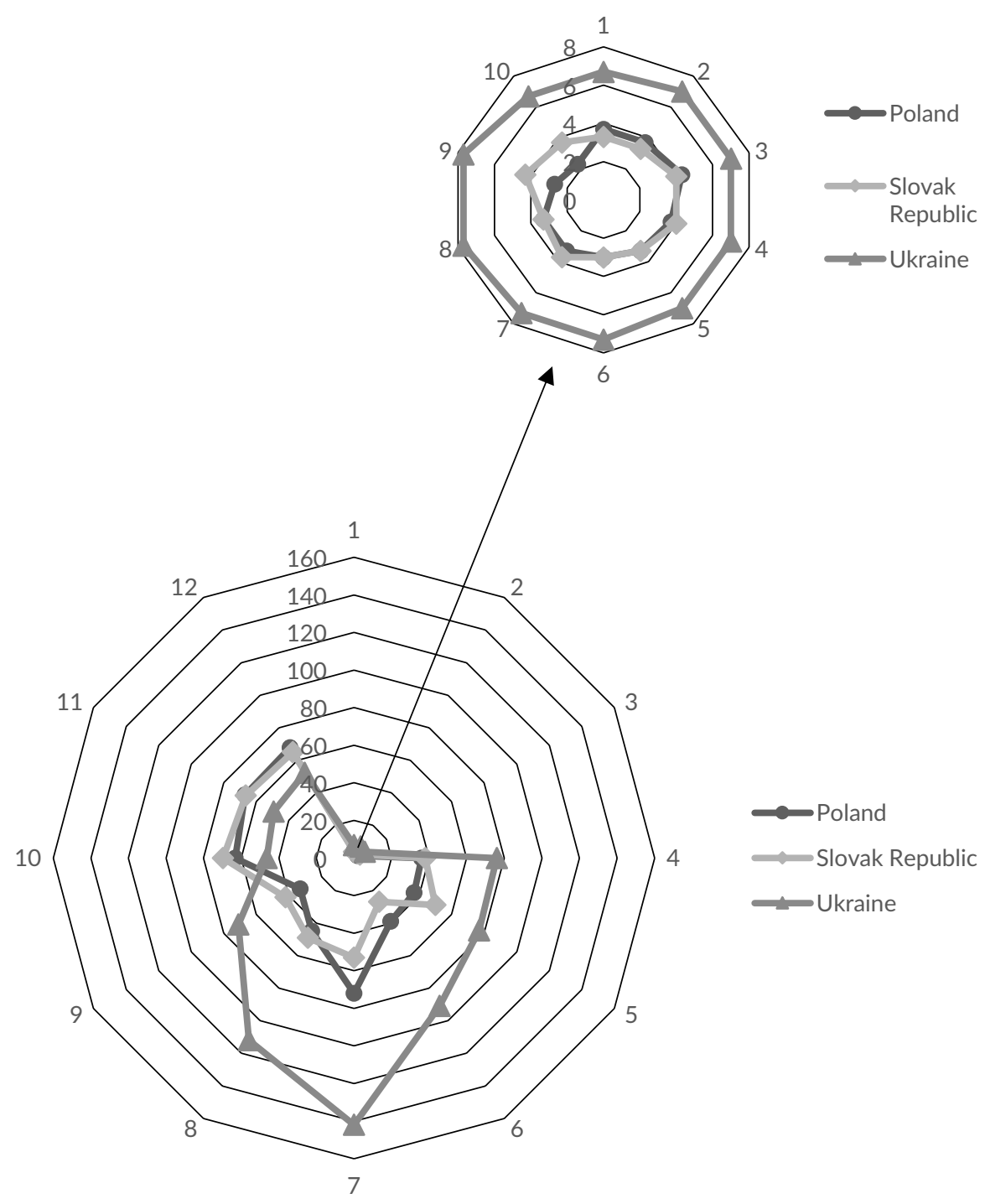

Figure 1. Criteria and indicators of the bank cards market for Poland, Slovakia and Ukraine Source: own study.

So, the pandemic and quarantine restrictions accelerated the shift in households' payment habits towards cashless settlements, including online payments. Ukrainians are more actively switching to cashless payments and are using electronic commerce services increasingly often. At the same time, there has been a sustainable trend 
in which contactless payment instruments and settlements involving their use are increasing in popularity. This trend has mainly resulted from an increase in the value and number of cashless transactions. Thus, the value of cashless transactions stood at UAH 1,550.1 billion, or $55.2 \%$ of the total value of all card transactions. In September 2019, it amounted at 49.7\% (Undeniable Card Market Trends in 2020).

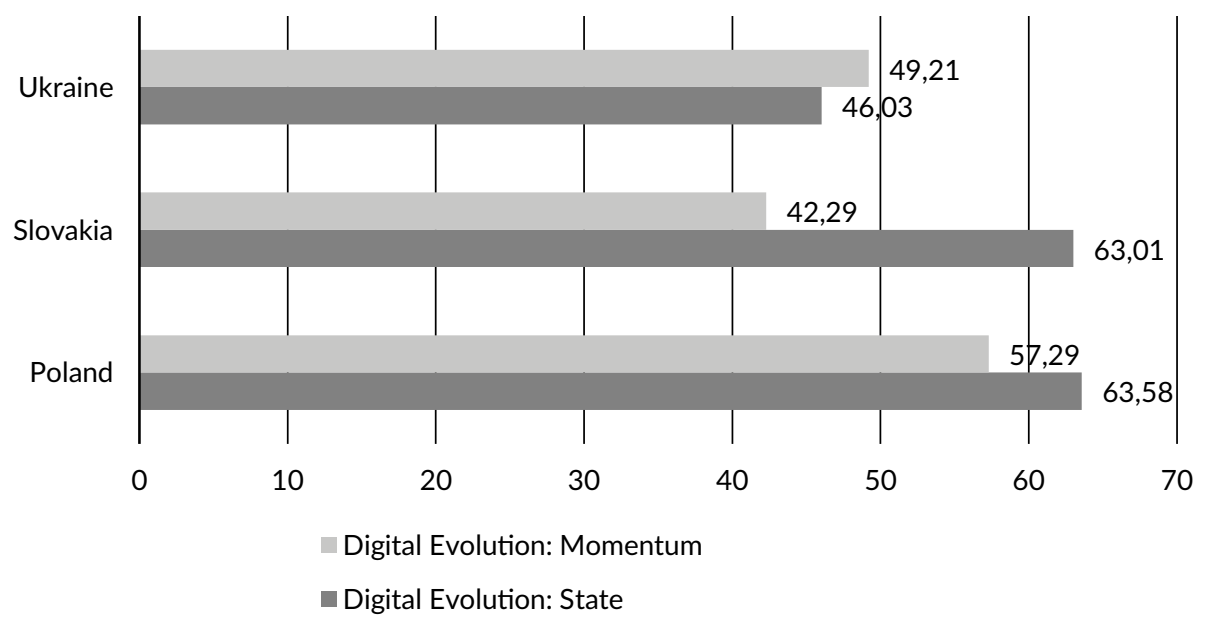

Figure 2. Digital Evolution Scores of Poland, Slovakia, Ukraine Source: Chakravorti, Chaturvedi, Filipovic, Brewer (2020).

Thus, innovative payment technologies and the relevant infrastructure play a key role in the development of the cashless economy. Ukraine has tremendous potential in implementation of payment innovations in comparison with Poland.

This is why future research in these three variables of the bank cards market will be very important. They will help explain the reasons for success and failure, and identify the challenges that lie ahead in strengthening the bank cards market in CEECs.

\section{The comparison of the bank cards market of Ukraine and Poland}

The level of development of the bank cards market has an important place in the banking system's development. However, the level of the bank cards market is a particular concept, and it is obvious that there is no perfect indicator that characterizes it. In the phase of Euro-integration, Ukraine has faced difficult tasks such as implementing and complying with the Basel III regulations in Ukrainian banking system. During digitalization and the challenge of the COVID-19 pandemic, many countries faced the need to implement digital cards, develop contactless payments, and stabilize the banking system. 
Ukraine and other countries urgently need solutions. The bank cards market is the most dynamic part of the banking sector. As bank cards combine elements of payment, deposit, credit, and currency-exchange functions, the bank cards market is a simplified model of the banking system.

Comparing the rankings of Ukraine and Poland shows that these countries' models are similar, although the countries are ranked differently according to "The Legatum Prosperity Index," "Doing Business," and "The Index of Economic Freedom". "The Legatum Prosperity Index" and "Doing Business" rank Poland highly, while Ukraine has a low rank. Ukraine has high level of "The Index of Economic Freedom" while for Poland it is low. Therefore, using the experience of Poland, Ukraine has significant potential for economic development, including the development of the bank cards market.

The dynamics of the bank cards market indicators in Ukraine and Poland showed that the variables of the number of cards, the development of the ATM network, and the number of POS-terminals complement each other. In recent years, the relationship between these indicators has become more meaningful. Table 8 represents the changes in the bank cards market indicators in Ukraine and Poland in the years 2010-2019.

Table 8. The dynamics of the bank cards market indicators in Ukraine and Poland, 2010-2019

\begin{tabular}{|l|c|c|c|c|c|c|c|c|}
\hline \multirow{2}{*}{ Years } & \multicolumn{2}{|c|}{$\begin{array}{c}\text { Population, } \\
\text { thousands }\end{array}$} & \multicolumn{2}{c|}{$\begin{array}{c}\text { Number of bank } \\
\text { cards, thousands }\end{array}$} & \multicolumn{2}{c|}{ ATMs. } & \multicolumn{2}{c|}{ POS-terminals } \\
\cline { 2 - 9 } & Ukraine & Poland & Ukraine & Poland & Ukraine & Poland & Ukraine & Poland \\
\hline 2010 & 45,783 & 38,530 & 29,405 & 31,984 & 30,163 & 16,413 & 108,140 & 246,510 \\
\hline 2011 & 45,598 & 38,538 & 34,850 & 32,045 & 32,997 & 17,392 & 123,540 & 266,429 \\
\hline 2012 & 45,453 & 38,533 & 33,106 & 33,291 & 36,152 & 18,188 & 162,724 & 289,547 \\
\hline 2013 & 45,373 & 38,502 & 35,622 & 34,659 & 40,350 & 18,876 & 221,222 & 326,340 \\
\hline 2014 & 45,246 & 38,484 & 33,042 & 36,069 & 36,596 & 20,531 & 203,810 & 398,172 \\
\hline 2015 & 42,759 & 38,455 & 30,838 & 35,209 & 33,334 & 22,143 & 194,478 & 463,366 \\
\hline 2016 & 42,591 & 38,427 & 32,389 & 36,874 & 33,783 & 23,443 & 219,241 & 536,236 \\
\hline 2017 & 42,415 & 38,422 & 34,858 & 39,096 & 37,003 & 23,230 & 251,681 & 624,434 \\
\hline 2018 & 42,153 & 38,413 & 36,949 & 41,237 & 36,585 & 22,885 & 278,993 & 786,845 \\
\hline 2019 & 41,902 & 38,390 & 42,158 & 42,854 & 35,930 & 22,720 & 333,840 & 906,564 \\
\hline
\end{tabular}

Source: data from National Bank of Ukraine (n.d.), Statistics; Narodowy Bank Polski (n.d.).

We can see improvements in both countries, although the situation in Poland is much better than in Ukraine. In both countries, the number of bank cards showed frequent fluctuations in indicators between 2010 and 2014, and annual growth between 2015 and 2019. Over the past 10 years, the number of ATMs has increased by $19 \%$, from 30,163 to 35,930 in Ukraine, and in Poland by 38\%, from 16,413 to 22,720. During this period, the number of POS terminals increased 3.1 times, from 108,140 to 333,840 in Ukraine, and in 3.7 times in Poland, from 246,510 to 906,564. Although the bank cards market in Ukraine, in particular, the number of POS-terminals, is developing and expanding, the growth rates are still low and insufficient in comparison with Poland. 
At the same time, over the last 10 years the population has decreased in both countries: from 45.7 million to 41.9 million (-8.5\%) in Ukraine, and from 38.5 million to 38.4 million $(-0.5 \%)$ in Poland. The indexes proposed and calculated by the authors show that in Poland, the following components are higher compared to Ukraine: the Number of bank cards per capita (1.12) and the Number of cards per ATM (more than 1,880). The same indicators accounted for slightly more than 1,010 and 1,170 in Ukraine, respectively. In this case, a comparative analysis of the relative indicators of the bank cards market is more accurate than the absolute ones.

Table 9. Indices of the bank cards market in Ukraine and Poland, 2010-2019

\begin{tabular}{|l|c|c|c|c|c|c|}
\hline \multirow{2}{*}{ Years } & \multicolumn{2}{|c|}{ Cards per capita, pcs. } & \multicolumn{2}{c|}{ Cards per ATM. } & \multicolumn{2}{c|}{ Cards per POS-terminal. } \\
\cline { 2 - 7 } & Ukraine & Poland & Ukraine & Poland & Ukraine & Poland \\
\hline 2010 & 0.64 & 0.83 & 975 & 1949 & 272 & 130 \\
\hline 2011 & 0.76 & 0.83 & 1056 & 1843 & 282 & 120 \\
\hline 2012 & 0.73 & 0.86 & 916 & 1830 & 203 & 115 \\
\hline 2013 & 0.79 & 0.90 & 883 & 1836 & 161 & 106 \\
\hline 2014 & 0.73 & 0.94 & 903 & 1757 & 162 & 91 \\
\hline 2015 & 0.72 & 0.92 & 925 & 1590 & 159 & 76 \\
\hline 2016 & 0.76 & 0.96 & 958 & 1573 & 148 & 69 \\
\hline 2017 & 0.82 & 1.02 & 942 & 1683 & 139 & 63 \\
\hline 2018 & 0.88 & 1.07 & 1010 & 1802 & 132 & 52 \\
\hline 2019 & 1.01 & 1.12 & 1173 & 1886 & 126 & 47 \\
\hline
\end{tabular}

Source: own calculations based on data from the National Bank of Ukraine (n.d.), Statistics; Narodowy Bank Polski (n.d.).

Table 9 describes the main indexes of bank card market in Ukraine and Poland between 2010 and 2019. The Number of bank cards per POS terminal decreased (or the Number of POS terminals per thousand bank cards increased) in both countries. The Number of bank cards per capita in Ukraine increased from 0.64 to 1.01, meaning that cashless payments had an upward trend during the period. Regarding Poland, the number of bank cards per capita increased from 0.83 to 1.12 . So, there was an expansion tendency for cashless payments in Poland, too.

The deepening cooperation between Ukraine and Poland in the framework of Euro-integration could contribute to the development of the bank cards market of both countries. However, it is not a short-term process. For some time, Ukraine has had to overcome many humanitarian (Covid-19, global warming), political (annexation of the Crimea, military operations in Donbas), and economic challenges (euro-integration, digitalization). All these factors will influence the development of the bank cards market in the near future. 


\section{Conclusion}

The strategies for the development of the bank cards market in every country in Central and Eastern Europe has different directions. This is reflected in the ranking of countries on "The Legatum Prosperity Index," "Doing Business," "The Index of Economic Freedom," and the "BCM Index".

Therefore, it is suggested that countries use the recommended methodology for a rapid review of the bank cards market. Periodic upgrading and in-depth analysis of the "BCM Index" will ensure that the data is always relevant to reliably compare the risks and opportunities of the market. This methodology provides a solid foundation for decision-making about investments and innovations in financial and banking spheres.

Ukraine should therefore seek to achieve a high level of digitalization, a cashless economy, a well-developed payment infrastructure, and the use of innovative payment tools. The pandemic and quarantine restrictions accelerated the change in cardholders' payment habits towards cashless settlements, including online payments. Cardholders are more actively switching to cashless payments and are increasingly using electronic commerce services. At the same time, there has been a sustainable trend in which contactless payment instruments and settlements involving their use are increasing in popularity. In the near future, all this will influence the development of the bank card market.

Finally, future research should be conducted in other developed and developing economies using the same methodology as in the current study to examine whether an association between the BCM Index and the level of economic development is found to be consistent.

\section{References}

Banca Naţională a României, Payments Statistics, http://www.bnr.ro/Payments-Statis tics-5312.aspx (accessed: 18.01.2021).

Bank of the Russia, National Payment System, http://www.cbr.ru/eng/statistics/nps/ (accessed: 18.01.2021).

Chakravorti, B., Chaturvedi, R.S., Filipovic, Ch., Brewer, G. (2020), Digital in the time of Covid. Trust in the Digital Economy and Its Evolution Across 90 Economies as the Planet Paused for a Pandemic, https://sites.tufts.edu/digitalplanet/files/2021/03/di gital-intelligence-index.pdf (accessed: 18.01.2021).

Fedorova, A.Y., Dorozhkina, N.I., Cherkashnev, R.Y. (2016), Organization of the market of Bank cards, "Arkhivarius", 8 (12), https://cyberleninka.ru/article/n/organizat ion-of-the-market-of-bank-cards (accessed: 18.01.2021).

Khetagurov, G.V. (2018), Development Trends in the Global Payment Card Market, "Journal of the Ural State University of Economics", 19 (1), pp. 16-24, https://doi .org/10.29141/2073-1019-2018-19-1-2 
The Development and Transformation of the Bank Card Market as an Imperative for Digitalization...

Klement, L., Lesáková, L., Klementová, V., Elexa, L. (2016), Innovation performance of the Slovak Republic, "Journal of Forum Scientiae Oeconomia”, 4 (3), pp. 115-126.

Legatum Prosperity Index (2020), Prosperity rankings: Full data set, https://www.pros perity.com/about/resources (accessed: 18.01.2021).

Miller, T., Kim, A.B., Roberts, J.M. (2019), 2019 Index of Economic Freedom, https:// www.heritage.org/index/pdf/2019/book/index_2019.pdf (accessed: 18.01.2021).

Národná Banka Slovenska, Payment systems, https://www.nbs.sk/sk/platobne-systemy (accessed: 18.01.2021).

Narodowy Bank Polski, Payment System, http://www.nbp.pl/homen.aspx?f=/en/syst em_platniczy/system_cards.html (accessed: 18.01.2021).

National Bank of Moldova, BNM Reports Generator, http://www.bnm.md/bdi/pages /reports/dsp/DSP1.xhtml (accessed: 18.01.2021).

National Bank of Ukraine, Cashless Payments, https://bank.gov.ua/en/payments/no cash (accessed: 18.01.2021).

National Bank of Ukraine, Statistics, https://bank.gov.ua/en/statistic (accessed: 18.01.2021).

National Bank of Ukraine (2020), Undeniable Card Market Trends in 2020: Online Settlements and Contactless Payments, https://bank.gov.ua/en/news/all/bezzapere chni-trendi-kartkovogo-rinku-u-2020-rotsi--rozrahunki-v-interneti-ta-bezkontak tni-plateji (accessed: 18.01.2021).

Panibratov, A., Ribberink, N., Veselova, A., Nefedov, K. (2018), Entry modes and liability offoreignness effects: evidence from Russian firms on the German market, "Journal of Organizations and Markets in Emerging Economies”, 9 (1), pp. 106-122, https:// doi.org/10.15388/omee.2018.10.00006

Ramskyi, A., Loiko, V., Sobolieva-Tereshchenko, O., Loiko, D., Zharnikova, V. (2017), Integration of Ukraine into the European banking system: cleaning, rebooting and Basel III , "Journal of Banks and Bank Systems", 12 (4), pp. 163-174, https://doi.org /10.21511/bbs.12(4-1).2017.05

Slovak Banking Association (2021), Štatistika vydávania a prijímania platobných kariet, https://www.sbaonline.sk/novinka/statistika-vydavania-a-prijimania-platobn ych-kariet (accessed: 18.01.2021).

Sobolieva-Tereshchenko, O. (2018), The Bank Card Market: a Comparative Analysis of Ukraine and its Neighboring Countries, "Comparative Economic Research. Central and Eastern Europe”, 21 (4), pp. 25-44, https://doi.org/10.2478/cer-2018-0025

Statistical Data Warehouse, Payments and Settlement Systems Statistics, https://sdw .ecb.europa.eu/browse.do? node=9691545 (accessed: 18.01.2021).

Świecka, B., Terefenko, P., Paprotny, D. (2021), Transaction factors" influence on the choice of payment by Polish consumers, "Journal of Retailing and Consumer Services", 58, https://doi.org/10.1016/j.jretconser.2020.102264

The Magyar Nemezeti Bank, Payment data, http://www.mnb.hu/en/statistics/statisti cal-data-and-information/statistical-time-series/xiv-payment-systems/payment-da ta (accessed: 18.01.2021).

The National Bank of the Republic of Belarus, https://www.nbrb.by/publications/bul letin (accessed: 18.01.2021). 
Van, D.T.T., Linh, N.H. (2019), The Impacts of Financial Inclusion on Economic Development: Cases in Asian-Pacific Countries, "Comparative Economic Research. Central and Eastern Europe”, 22 (1), pp. 7-16, https://doi.org/10.2478/cer-2019-0001

Verisk Financial, Payment Industry Trends. Europe, https://www.veriskfinancialresea rch.com/reports/country-reports/europe.html (accessed: 18.01.2021).

World Bank Group (2018), Doing Business 2018. Reforming to Create Jobs, International Bank for Reconstruction and Development/The World Bank, Washington https:// www.doingbusiness.org/content/dam/doingBusiness/media/Annual-Reports/Eng lish/DB2018-Full-Report.pdf (accessed: 18.01.2021).

World Bank Group (2019), Doing Business 2019. Training for Reform, International Bank for Reconstruction and Development/The World Bank, Washington, https:// www.doingbusiness.org/content/dam/doingBusiness/media/Annual-Reports/Eng lish/DB2019-report_web-version.pdf (accessed: 18.01.2021).

\section{Rozwój i transformacja rynku kart bankowych jako imperatyw cyfryzacji na przykładzie krajów Europy Środkowo-Wschodniej}

Celem niniejszego opracowania jest określenie trendów rozwojowych głównych determinant rynku kart bankowych w ośmiu krajach Europy Środkowo-Wschodniej w okresie 2010-2019. Kontynuując badanie przeprowadzone w 2018 r. przeprowadzono dalszą analizę porównawczą zaproponowanego wcześniej „Indeksu Rynku Kart Bankowych” opartego na systemie powiązanych ze sobą wskaźników bankowych kart płatniczych, bankomatów i terminali POS. Przedstawiono przegląd rankingów Ukrainy, Białorusi, Mołdawii, Rosji, Rumunii, Polski, Węgier i Słowacji przy użyciu międzynarodowych systemów rankingowych, takich jak „The Legatum Prosperity Index”, „Doing Business”, "The Index of Economic Freedom” i „Bank Cards Market Index”. Dalsze badania trzech międzynarodowych systemów rankingowych, a także „Bank Cards Market Index” ponownie potwierdziły podobieństwo modeli rozwoju rynku kart bankowych w Polsce i na Ukrainie. Aby zbadać wpływ cyfryzacji gospodarki i pandemii Covid-19 na rynek kart bankowych, przeprowadzono pogłębioną analizę dwóch przypadków (Polski i Ukrainy jako dwóch podobnych rynków kart bankowych) za pomocą "Digital Evolution Index”. W trakcie badań stwierdzono, że „Bank Cards Market Index” może być z powodzeniem wykorzystany do dalszych badań sektora bankowego w różnych krajach. Zauważono również trend wzrostowy płatności bezgotówkowych na rynku kart bankowych i możliwą transformację rynku pod wpływem Covid-19 oraz globalną cyfryzację gospodarki. Biorąc pod uwagę powyższy trend, dalsze badania systemu powiązanych wskaźników bankowych kart płatniczych, bankomatów i terminali POS powinny być prowadzone z wykorzystaniem „Digital Evolution Index” lub innych międzynarodowych wskaźników charakteryzujących poziom cyfryzacji gospodarki w badanych krajach.

Słowa kluczowe: Bank, Polska, Ukraina, karty bankowe, wskaźniki, ranking krajów, indeks, gospodarka cyfrowa, cyfryzacja 
The Development and Transformation of the Bank Card Market as an Imperative for Digitalization...

\begin{tabular}{|l|l|}
\hline CC C) by the author, licensee Łódź University - Łódź University Press, \\
tódź, Poland. This article is an open access article distributed under \\
the terms and conditions of the Creative Commons Attribution \\
license CC-BY-NC-ND 4.0 \\
(https://creativecommons.org/licenses/by-nc-nd/4.0/) \\
Received: 2021-02-01. Verified: 2021-06-20. Accepted: 2021-08-11.
\end{tabular}

